doi:10.18575/msrs.sm.e.16.23

UDK 616.36-002:615.2

COBISS.RS-ID 6165016

\title{
Drug Induced Liver Injury: Pathogenesis, Clinical Features and Monitoring
}

\section{ABSTRACT}

Introduction: Drug-induced liver injury (DILI) is a rare but potentially life threatening adverse drug reactions. DILI may mimic pathophysiology or histopathologic features of an acute or chronic liver disease, and they may be indistinguishable from those of other causes of liver injuries. Liver can be affected directly, in a dose-dependent manner, or idiosyncratically, independently of the dose, and therefore unpredictably developed.

Methods: In this special article we provided results given in the articles published in PubMed in the period 2006-2016. The search was made based on the most frequent reported drugs inducing liver injuries, diagnostic assessment, monitoring and outcomes of DILI.

Results: The true incidence of DILI still remains unknown but the incidence of up to 14 cases per 100,000 inhabitants/year has been most frequently reported. Antimicrobial agents, analgesics, hipolipemics and antiepileptics are the most common drugs causing DILI.

Conclusion: Although several biomarkers have been found through analytical tests, none of them have been able to display enough specificity and sensitivity in DILI diagnosis. Therefore, diagnostic assessment of DILI is still based on clinical examination, pharmacological treatment history, current RUCAM criteria, and liver function laboratory test.

Key words: drugs, hepatotoxicity, idiosyncrasies, pharmacogenetics, RUCAM criteria

\section{Ana Ćurguz, Lana Nežić, ${ }^{2}$ Danijela Mandić, 3}

${ }^{1}$ Division of Pharmacy, School of Medicine, University of Banja Luka, $780 o o$ Banja Luka, Bosnia and Herzegovina

${ }^{2}$ Department of Pharmacology, Toxicology and Clinical Pharmacology, School of Medicine, University of Banja Luka, $780 o o$ Banja Luka, Bosnia and Herzegovina ${ }^{3}$ Clinic of Internal Medicine, University Clinical Center of the Republic of Srpska, 7800 o Banja Luka, Bosnia and Herzegovina

\section{Contact address:}

Lana Nežić,

14 Save Mrkalja St, $780 o o$ Banja Luka, Bosnia and Herzegovina Telephone: +38751234100 E-mail:lanne@doctor.com

Submitted: September 13th, 2016 Accepted: September 21st, 2016 


\section{Introduction}

Drug-induced liver injury (DILI) is defined as the damage caused by drug or herbal medications, leading to liver dysfunction, with or without the histopathological changes.1 According to the recently published prospective epidemiological study, the annual incidence of DILI was 13.9 cases/100,000 inhabitants in the period from 1997 to 2000 in France, 12/100 ooo inhabitants in 20052007. in Korea, 19.1/100,000 inhabitants in 2010-2011 in Iceland, and 2.4 cases / 100,000 inhabitants in the oneyear follow-up in the United Kingdom. Today, in Asian countries, herbal medicines used in traditional medicine represent a major cause of DILI (over 90 cases / 100,000 inhabitants/year). ${ }^{1,2}$ Although DILI incidence is difficult to clearly determine due to many confusing (confounding) factors and under-reporting of adverse reactions to drugs (ADR), World Health Organization reports an increase in the incidence since $1990 .{ }^{3}$

\section{Clinical forms of DILI}

According to clinical, biochemical and histological characteristics, DILI can manifest in all forms of acute and chronic liver damage. Consequently, DILI may develop acute liver failure (ALF), acute hepatitis with and without jaundice, chronic hepatitis (rarely results in cirrhosis of the liver), or only as asymptomatic increase of liver enzymes. In a significant number of patients (25-30\%), DILI is manifested in the form of immunoallergic drug reactions with the development of fever, rash and eosinophilia. ${ }^{1-4}$ The aim of this review is to present the results of epidemiological, clinical and pre-clinical research, published in scientific publications cited in the database PubMed, in the period from 2006 to 2015. Publications are selected according to the following criteria: drugs that frequently cause DILIs, diagnostic criteria for causal assessment of DILI, monitoring the clinical status and laboratory parameters and outcomes of DILI. This review did not consider research related to DILI in children and those caused by herbal medicines and toxins.

\section{Classification of DILI}

$\mathrm{Na}$ Based on histopathological and pathophysiological outcomes of liver damage, DILIs are classified as hepatocellular, cholestatic and mixed..$^{5-7}$ This classification is of great importance as it contributes to prognosis and outcome of DILI. The classification based on patterns of laboratory changes in liver enzymes found in DILI was first proposed by the Council for International Organization of Medical Sciences, and modified by the Food Drug Administration (FDA)- Drug Hepatotoxicity Steering Committee. ${ }^{5}$ Assessment of liver function is usually based on the activity of the enzyme alanine aminotransferase (ALT) and alkaline phosphatase (AP) that consist proposed biochemical DILI classification (Table 1$).{ }^{5}$
Table 1. Drug induced liver injuries based on liver enzymes laboratory findings ${ }^{5}$

\begin{tabular}{|c|c|}
\hline Liver injury type & Laboratory calculation \\
\hline Hepatocellular & $\begin{array}{c}A L T \geq 3 \times \text { ULN i } R=\text { "(ALT/ULN)" /"(AP/ } \\
\text { ULN)" “ } \geq 5 " \\
\text { ALT } \leq 3 \times \text { ULN - } \\
\text { non significant liver dysfunction. }\end{array}$ \\
\hline Cholestatic & $\begin{array}{c}\mathrm{AP} \geq 2 \times \mathrm{ULN} \text { i } \mathrm{R}= \\
\leq 2 \\
\mathrm{AP}<2 \times \mathrm{ULT} / \mathrm{ULN} \text { " /"AP/ULN" } \\
\text { non significant liver dysfunction. }\end{array}$ \\
\hline Mixed & $\begin{array}{c}A L T \geq 3 \times \text { ULN i AP } \geq 2 \times \text { ULN } \\
R==\text { "(ALT/ULN)" /"(AP/ULN)" }>2 \text { “i }< \\
5 " .\end{array}$ \\
\hline
\end{tabular}

Hepatocellular damage is associated with an increase in transaminases, which is usually normalize weeks after discontinuation of the drug. However, asymptomatic deterioration in liver function sometimes normalizes despite continued administration of the drug, and this phenomenon is called adaptation. ${ }^{4-6}$ The phenomenon of adaptation was first observed in studies with isoniazid, when in $20-30 \%$ of treated patients, a moderate increase in transaminases occurred, which was later followed by decrease of these values to the reference levels, despite continued administration of the drug. It is assumed that the mechanism of adaptation includes "up and down" regulation of transport molecules and enzymes involved in drug metabolism, development of tolerance and finally, liver regeneration.5,6 Clinically cholestatic liver damage caused by medications can manifest as fever, pain similar to acute biliary obstruction or chronic jaundice associated with itching. Regeneration of cholangiocytes is slower compared to hepatocytes, and recovery of cholestatic markers tends to decrease over the next 6-9 months. ${ }^{6,8}$ One of the main indicators of prognosis of acute DILI is the presence of jaundice. Tests have shown that DILI associated with the increase of bilirubin levels greater than 3 times the upper reference value, in the absence of biliary obstruction and Gilbert's syndrome, is associated with an average mortality rate of about $10 \%$ (range $5-50 \%$ mortality).4,5,9 This clinical and biochemical pattern is known as Hy's law, named after the Swiss scientist Hyman Zimmerman, who first determined this relation. ${ }^{6,8}$ Additionally, the criteria according to Hy's law is accepted by the FDA as an indicator of serious toxicity and is used to assess drug safety in clinical trials. ${ }^{6}$ However, more sensitive and specific indicators of liver damage are ALT> 8-10 x ULN (Upper Limit of Normal) or ALT> $3 \times$ ULN associated with the level of bilirubin $>2 \times$ ULN (modified Hy's Law ).$^{5-8}$ In the combined DILI, there is a combination of acute hepatitis and cholestasis. It has been shown that drugs that cause cholestatic, can cause combined DILI and 
vice versa.

\section{The mechanism of drug hepatotoxicity}

U Directly (intrinsic) and liver damage caused by idiosyncrasies are involved in the mechanism of drug hepatotoxicity involved. ${ }^{10,11}$ Drugs that cause intrinsic DILI exhibit direct hepatotoxic effect as the active substance, or indirectly as a metabolite, and it is the most commonly dose-dependent e.g. paracetamol. Since the liver is the main organ for metabolism and detoxification of drugs, those that have significant hepatic metabolism usually cause DILIs. Reactions of idiosyncrasies can be immunological and non-immunological pathogenesis, often independent of the dose of administered drug. The immune-mediated (hypersensitivity) reactions idiosyncrasies are often associated with fever, skin rash, and eosinophilia, as well as presence of specific antibodies. ${ }^{2,3}$ Additional sign-mediated immune response is rapid occurrence and more difficult recurrent clinic state, if the drug is re-administered.5.11 Non-immunologically mediated idiosyncratic reactions are not usually associated with the above mentioned signs. Both, immunologically or non-immunologically mediated DILI are manifested in the form of hepatocellular or cholestatic/combined type. ${ }^{6,7}$ The majority of clinically visible cholestatic hepatitis and combined/cholestatic reactions are associated with damage and inflammation of the bile ducts. It is assumed that a metabolite of the drug is subject to canalicular excretion, which expose epithelial cells of the bile ducts to direct toxic effects or immunologic sensitization of the metabolite. ${ }^{7}$ Idiosyncrasies are associated with inflammation of liver tissue, while intrinsic DILI is characterized by fields of necrosis, and hepatocytes apoptosis of with minimal inflammation. ${ }^{10}$

\section{Latency period to clinical manifested DILI}

According to predictability, DILI can be classified as predictable and unpredictable. Predictable reactions caused by drugs appear relatively quickly after a short latency period (within a few days), dose-dependently (e.g. paracetamol), and as a result of direct action of the drug or indirectly of metabolites. Unpredictable reactions (idiosyncrasy to drugs) occur rarely, with various occurrences, sometimes with prolonged latent period (from one week to one year) and are not probably dosedependent. ${ }^{1,2,5,11}$ However, cases of DILI several weeks (amoxicillin / clavulanate or trovafloxacin) or months after exposure to nitrofurantoin or ximelagatran have been described. ${ }^{10}$

\section{The DILI outcome after discontinuation of TR causative hepatotoxic drug}

Asymptomatic and mild degree DILI is usually fully recovered after discontinuation of the causative drug. After the suspension of hepatotoxic drugs, indicators of liver damage can persist for weeks or even up to one year in case of cholestatic DILI. However, it is known that decrease in transaminase levels may be indicative of the ALF, before the recovery of its functions, due to massive necrosis of hepatocytes. Poor prognostic indicators of DILI are presence of coagulopathy and encephalopathy., ${ }^{4,11}$ Although patients with cholestatic DILI have a worse prognosis than patients with jaundice, which is not caused by the drug, most of them recover completely. Thus, it was shown that of 784 patients with cholestatic DILI associated with jaundice, $90.8 \%$ of them fully recovered, while $72(9.2 \%)$ patients died or had undergone liver transplantation.5,11 In addition, the results of several studies have shown that eosinophilic infiltration of the liver and eosinophils in peripheral blood were positive prognostic parameters that indicate a full recovery DILI. ${ }^{11}$

\section{Risk factors for DILI}

To date, factors that are responsible for the mechanism of hepatotoxicity, as well as the consequences of the complex interaction of the drug and the individual patient are recognized only for a few drugs or pharmacotherapeutic groups. ${ }^{2}$ Sensitivity to the development of DILI is the result of the interaction of various factors such as age, sex, drug interactions with hepatotoxic potential, environmental factors (alcohol, low protein diet, toxins, environment and food), chronic liver disease, comorbidities, obesity and genetic predisposition. In general, the elderly and women showed greater sensitivity to the drug which causes liver damage, while children are more sensitive to valproic acid and erythromycin., ${ }^{2,711}$ One research included cases with ALF, and showed that paracetamol often causes ALF particularly in women (74\% of all cases of paracetamol$\mathrm{ALF}$ ), and the idiosyncracies (67\%). ${ }^{5}$ Risk factors such as malnutrition and alcohol consumption threaten liver function and promote the consumption of glutathione and potentiate the toxicity caused by paracetamol..$^{5-7}$ Pharmacogenetics development has shown that genetic polymorphisms of drug metabolic pathways are the most important determinant for the development of DILI. ${ }^{12-14}$ Genetic polymorphism of N-acetyltransferase 2 and CYP (cytochrome) 2E1 are linked to predisposition for the development of hepatotoxicity of antituberculosis drugs, especially isoniazid..$^{12}$ Antiepileptic, valproate acid often causes DILI in children, probably because of the immaturity of $\mathrm{CYP}_{2} \mathrm{C} 9$, interactions with other antiepileptic drugs and the genetic polymorphism of mitochondrial DNA, which leads to the formation of reactive metabolites and mitochondrial damage in hepatocytes. ${ }^{12}$ Hepatotoxicity of lipophilic statins in the elderly occurs as a result of a functional polymorphism of $\mathrm{CYP}_{3} \mathrm{~A}_{4}$, decreased clearance and drug interactions with other inductors or CYP inhibitors.13 Diclofenac is the most common cause of DILI of all NSAIDs, which are associated with the genetic polymorphism of metabolizing enzymes CYP2C8, UDPGT 2B7, GST) and hepato-canalicular transporters (BSEP, 
MRP2, MRP4) polymorphism of antioxidant enzymes and interactions at the level of cytochrome, creating a reactive metabolite, damaged antioxidant mechanism and reduced clearance of the drug. ${ }^{12-14}$

DILI caused by a combination of amoxicillin and clavulanic acid has been associated with certain human leukocyte antigen halotype (HLA), which contributes to the changed immune response to drug, then genetic polymorphism of canalicular transport molecules (ABCB4), which contributes to exposure of biliary tract to metabolites and development of cholestatic or combined liver damage. ${ }^{5,12,14}$ SCL transporter polymorphism (OAT1PB1), which is responsible for the drug influx to enterocytes and hepatocytes, is associated with hepatotoxicity induced by methotrexate, statins, bosentan, rifampicin and troglitazone.

It is also known that structurally similar drugs can cause DILI, and that there is cross-reactivity and toxicity confirmed in DILI cases induced by different aromatic anticonvulsants (phenytoin, phenobarbital and carbamazepine), ACE inhibitors (captopril and enalapril), NSAIDs, and drugs of phenothiazine tricyclic antidepressants. ${ }^{12-14}$

\section{Diagnostic assessment of the occurrence of DILI}

The lack of objective diagnostic tests, or specific / sensitive biomarker for DILI, and various clinical manifestations are often the reason for late diagnosis of DILI. ${ }^{9}$ In 2013, National Institute of Diabetes, kidney and digestive tract proposed the establishment of Drug-Induced Liver Injury Network (DILIN) as a system for registration, evaluation and diagnosis of drug hepatotoxicity, drugs in the daily practice and those in clinical trials. ${ }^{9}$
The key diagnostic elements for DILI, in addition to laboratory findings, belongs to the pharmacological anamnesis and evaluation of the following factors: start of DILI, clinical features, course of disease and recovery, risk factors, the exclusion of other diagnoses, as well as knowledge of the hepatotoxic potential of the drug. In addition, the most accurate diagnosis of DILI would be an exposure to a suspected drug, so called re-challenge and/ or liver biopsy, although these are not always ethically justified procedures for patient safety nor DILI express typical histopathological findings. ${ }^{9}$ In general, diagnosis of DILI is based on the evaluation of liver biochemical tests, including ALT and AP, additionally aspartate aminotransferase (AST), gamma-glutamyl transpeptidase (GGT) and bilirubin, and on that basis determine the biochemical classification of DILI. ${ }^{9}$ The difference in ALT and AP expresses ratio (R), taking into account their ULN. $\mathrm{R}=$ ratio of $\mathrm{ALT} / \mathrm{AP} \geq 5$ denotes hepatocellular injury, and the ratio $\mathrm{R} 2$ denotes $\leq$ cholestatic injury, while $\mathrm{R} 2$ and 5 are classified as DILI combined (Table 1 )..$^{5-8}$

\section{Preview of the drugs that commonly cause DILI}

One of the earliest comprehensive studies of drugs that cause liver injury, causation and assessment of illness severity, was conducted in the international study (DILI Network Study), which analyzed the reported cases of DILI, in the three registers in Spain, Sweden and the United States, from 2004 to $2007 .{ }^{15}$ The study included all patients $(\mathrm{n}=1734)$ diagnosed with DILI based on clinical, biochemical findings and CIOMS/RUCAM criteria. There were 319 identified drugs with the highest probability for DILI, such as amoxicillin-clavulanic acid, flucloxacillin, erythromycin, diclofenac, sulfamethoxazole / trimethoprim, nitrofurantoin, isoniazid, combinations of antituberculotic drugs, and other drugs (Table 2).

Table 2. Comparison of 20 most frequent drugs causing DILI among three DILI registries (2004-2007) ${ }^{15}$

\begin{tabular}{ccccc}
\hline Drug & $\begin{array}{c}\text { Total number of DILI } \\
\text { reports }\end{array}$ & $\begin{array}{c}\text { Spanish registry } \\
(\mathrm{n}=650)\end{array}$ & $\begin{array}{c}\text { Swedish registry } \\
(\mathrm{n}=784)\end{array}$ & $\begin{array}{c}\text { USA registry } \\
(\mathrm{n}=300)\end{array}$ \\
\hline Amoxicillin / clavulanate & 136 & 105 & 5 & 26 \\
\hline Flucloxacillin & 129 & - & 129 & - \\
\hline Erythromycin & 48 & 6 & 42 & 3 \\
\hline Diclophenac & 38 & 16 & 19 & 10 \\
\hline Co-trimixazole & 34 & 2 & 22 & 13 \\
\hline Isoniasid & 31 & 11 & 7 & 3 \\
\hline Disulfiram & 31 & 1 & 6 & 1 \\
\hline Ibuprofen & 28 & 21 & 16 & 3 \\
\hline Carbamazepine & 26 & 7 & 4 & 18 \\
\hline Nitrofurantoin & 24 & 2 & 2 & 10 \\
\hline Paracetamol & 24 & 12 & 7 & - \\
\hline Ticlopidine & 20 & 13 & - & - \\
\hline Antituberculotics & 19 & 19 & & \\
\hline
\end{tabular}




\begin{tabular}{ccccc}
\hline Drug & $\begin{array}{c}\text { Total number of DILI } \\
\text { reports }\end{array}$ & $\begin{array}{c}\text { Spanish registry } \\
(\mathrm{n}=650)\end{array}$ & $\begin{array}{c}\text { Swedish registry } \\
(\mathrm{n}=784)\end{array}$ & $\begin{array}{c}\text { USA registry } \\
(\mathrm{n}=300)\end{array}$ \\
\hline Valporate & 18 & 9 & 2 & 7 \\
\hline Ciprofloxacine & 18 & 4 & 7 & 7 \\
\hline Halotan & 17 & 2 & 15 & - \\
\hline Levofloxacine & 15 & 5 & - & - \\
\hline Naproxen & 14 & 2 & 12 & 1 \\
\hline Statins & 11 & 10 & - & - \\
\hline Chlorpromazine & 11 & 3 & 8 & \\
\hline
\end{tabular}

A significant percentage of identified hepatotoxic drugs ( $n=265,83.1 \%$ ) was associated with at least one case of ALF. A prospective study of the same design was carried out in nine countries in Latin America, where the registers of DILI were established, in the period from 2011 to $2014 .{ }^{16}$ Out of 250 diagnosed cases of DILI, the most frequent pharmacotherapeutic group identified as ethiological factors were antimicrobial agents, non-steroidal antiinflammatory drugs (NSAIDs -diclophenac, ibuprofen and nimesulide) and sex hormones. However, somewhat different results were obtained in the analysis of DILI in Asia. In India, the antituberculotics were identified as the most common hepatotxins (58\% of all DILI), then antiepileptics (11\%), olanzapine (5\%) and dapsone (5\%). ${ }^{17}$ In the retrospective study in Chinese hospitals of tertiary level in the four-year period, there were confirmed diagnosis of DILI in 361 hospitalized patients, with an overall mortality rate of $8: 59 \%$ and the incidence of DILI 92.95/100,000 inhabitants. The most common type of DILI were hepatocellular (63.16\%), cholestatic (13.85\%) and the rest combined. Drugs and preparations that caused DILI were herbal preparations of traditional Chinese medicine (35.01\% of patients with DILI), antithyreoid (14.4\%, propylthiouracil, metamizole), antituberculosis drugs (14.13\%, respectively, and combined), then antibiotics (quinolones, cephalosporins, vancomycin), cytostatics (cisplatin, gemcitabine, etoposide), immunosuppressants (methotrexate, leflunomide), and statins.

In the recent period, in hepatology are raised questions related to hepatotoxicity of many drugs, as there were given the different type and quality of published scientific data (case reports vs. series of cases), differences in data on hepatotoxicity in the instructions for use of the drug between Europe and the United States, and other reasons. Recently, a web portal LiverTox® has been set up, through which it is possible to access most recent, reliable data on the diagnosis, prevalence and disturbances of liver function, for all drugs registered in the United States..$^{18}$ The number of reported cases of drugs that cause DILI are divided into four categories: category A> 50 the total of known cases reported to the establishment of the web portal, B> 12 but $<50$ cases, $\mathrm{C} 4>$ or $<12$, and D 1-3 confirmed cases of DILI, with additional fifth category $\mathrm{T}$ that refers to DILI caused by doses greater than therapeutic. According to the guidelines in LiverTox $\AA$, drugs categories A and B, especially drugs for which there is $>100$ reported cases of DILI, are undoubtedly hepatotoxicity drugs (antimicrobial drugs, NSAIDs, valproic acid, carbamazepine, phenytoin, statins, antispsyhotics-phenothiazines, oral contraceptives, amiodarone, interferon and anti-cancer drugs (methotrexate). ${ }^{18}$

\section{Preview of drugs that cause a variety of clinical and biochemical forms of DILI}

In the pathogenesis of DILI, the largest number of drugs hepatotoxicity is caused by non-immunological type, dosedependent form of hepatocellular damage (Table 3).5,6

Table 3. Drug induced hepatocellular hepatitis, cholestatic and/or mixed DILI form ${ }^{5}$

\begin{tabular}{|c|c|c|}
\hline Liver injury & Tip & Hepatotoxic drugs examples \\
\hline Hepatocellular & $\begin{array}{l}\text { Immunology mediated } \\
\text { mechanism }^{\mathrm{a}}\end{array}$ & $\begin{array}{l}\text { Alopurinol, diclophenac }{ }^{b} \text {, dihydralazine, halotan, methyildopa, minocyclin, nevirapine, } \\
\text { nitrofurantoin, phenitoine, propylthiouracil, trovafloxacin }\end{array}$ \\
\hline Hepatitis & $\begin{array}{l}\text { Non-immunology } \\
\text { mediated mechanism }\end{array}$ & $\begin{array}{l}\text { Acarbosis, amiodarone, bosentan, dantrolen, diclophenac }{ }^{\mathrm{b}} \text {, disulfiram, phelbamate, } \\
\text { flutamid, HAART treatment, statins, isoniasid, ketoconasole, labetalol, lephlunomide, } \\
\text { methotrexate, nefazodon, nevirapine, nicotinic acid, paracetamol, pyrazinamide, } \\
\text { rifampicin, tolcapone, troglitazone, valproate, ximelagatran, zafirlukast, zileutin }\end{array}$ \\
\hline $\begin{array}{l}\text { Cholestatic/ } \\
\text { Mixed }\end{array}$ & $\begin{array}{l}\text { Immunology mediated } \\
\text { mechanism }\end{array}$ & $\begin{array}{c}\text { ACE inhibitors, amytriptiline, amoxicilline/clavulanate, carbamazepin, chlorpromazine, } \\
\text { co-trimoxasole, erythromycine, phenobarbital, sulphonamide, sulindak, other tricyclic } \\
\text { antidepressants }\end{array}$ \\
\hline
\end{tabular}


a) Characterized by fever, rash, eosinophilia or antibodies appearance; Rapid, positive response in different cases;

b) Diclophenac related reactions can be mediated by immune or non-immune mechanism;

c) Non-immune mediated reaction is related to fever, rash, eosinophilia or antibodies appearance; HAART= activated antiretroviral therapy.

\section{DILI assessment criteria/ RUCAM scoring system}

The formal criteria for assessment of causality and probability of DILI was ordered by CIOMS, designed in 1990 by a hepatologists from Europe and the United States.

Today, assessment of drug hepatotoxicity is based on socalled Roussel-Uclaf assessment method causes (RousselUclaf causality assessment method - RUCAM), which is the scoring system with questions related to DILI. The system consists of seven criteria shown in Table $4 \cdot{ }^{15}$

Table 4. CIOMS/RUCAM criteria in DILI assessment ${ }^{15,19}$

\begin{tabular}{|c|c|c|c|c|c|}
\hline Liver injury type & \multicolumn{2}{|c|}{ Hepatocellular } & \multicolumn{2}{|c|}{ Cholestatic/Mixed } & \multirow{2}{*}{$\begin{array}{c}\text { Score } \\
/\end{array}$} \\
\hline Time to onset & Initial challenge & $\begin{array}{l}\text { Subsequnet } \\
\text { challenge }\end{array}$ & Initial challenge & $\begin{array}{l}\text { Subseq. } \\
\text { challenge }\end{array}$ & \\
\hline \multirow{2}{*}{$\begin{array}{c}\text { Time from the beginning of the } \\
\text { drug intake }\end{array}$} & 5-90 days & 1-15 days & 5-90 days & $1-90$ days & 2 \\
\hline & $<5$ ili $>90$ days & $>15$ days & $<5$ ili $>90$ days & $>90$ days & 1 \\
\hline Time from the drug cessation & $\leq 15$ days & $\leq 15$ days & $\leq 30$ days & $\leq 30$ days & 1 \\
\hline \multirow{2}{*}{ Risk factors } & \multicolumn{2}{|c|}{ Alcohol } & \multicolumn{2}{|c|}{ alcohol or pregnancy } & 1 \\
\hline & \multicolumn{2}{|c|}{ Age of patients $\geq 55$ years } & \multicolumn{2}{|c|}{ Age of patients $\geq 55$ godina } & 1 \\
\hline \multirow{5}{*}{ Course of reaction } & \multicolumn{2}{|c|}{$>50 \%$ improvement in 8 days } & \multicolumn{2}{|l|}{ / } & 3 \\
\hline & \multicolumn{2}{|c|}{$>50 \%$ improvement in 30 days } & \multicolumn{2}{|c|}{$>50 \%$ improvement in 180 days } & 2 \\
\hline & \multicolumn{2}{|l|}{1} & \multicolumn{2}{|c|}{$<50 \%$ improvement in 180 days } & 1 \\
\hline & \multicolumn{2}{|c|}{ No information or without improvement } & \multicolumn{2}{|c|}{ No information or without improvement } & 0 \\
\hline & \multicolumn{2}{|c|}{$\begin{array}{c}\text { Worsening or improvement }<50 \% \text { in } 30 \\
\text { days }\end{array}$} & \multicolumn{2}{|l|}{ / } & 1 \\
\hline
\end{tabular}

Based on the collected points, causality and probability of DILI is categorized as highly probable $(>8)$, probable (6-8), possible (3-5), is unlikely ( $1-2)$ or excluded $(\leq 0)$. RUCAM system is verified using the re-challenge and DILI cases proved more sensitive (86\%) and with higher specificity (89\%) compared to other earlier criteria. ${ }^{15,19}$

\section{Monitoring and preventive measures for the development of DILI}

Almost all drugs that cause liver damage lead to an increase in ALT levels. The increase of ALT $\leq 3 \mathrm{xULN}$ is associated with mild hepatic impairment, and it is also registered in placebo-controlled clinical trials (0.2-1\%). Although ALT> 3xULN is considered to be a sensitive marker for liver damage, this value is not specific only for DILI. Significantly more sensitive predictors of liver failure are considered as ALT $\geq 10 x U L N$, or elevated ALT and serum bilirubin of modified Hy's law. This finding suggests that the increase in serum bilirubin (except for Gilbert syndrome) indicates greater "attack" on liver or liver damage intense. FDA has proposed guidelines for the assessment of severe / serious degree of DILI as follows: ALT $\geq 8$ ULN, ALT $\geq 5$ ULN for 2 weeks, ALT $\geq 3$ ULN and serum bilirubin $\geq 2$ ULN with prothrombin time-INR $>1: 53$ or symptoms of liver failure. ${ }^{8,14}$ However, monitoring of ALT and serum bilirubin on a monthly basis, in the prevention of lifethreatening DILI, has its limitations. Monthly monitoring of liver function would be the choice, in cases when doctors and patients will adhere to regular controls. As an example, it is interesting to cite the case of manufacturer's warnings about hepatotoxicity of troglitazone and necessity of ALT monitoring, after which it was found that only $33 \%$ of patients in the first month and $13 \%$ in the fifth month of treatment had done this test. Secondly, strict monitoring of liver function can lead to interruption of application of necessary and effective medication. It is important to note that severe DILI occur early and despite monitoring of liver function (eg. troglitazone). Therefore, "waiting for" increase in ALT> 3xULN sometimes causes too late reaction to prevent DILI. ${ }^{8,14}$

Recent approach in understanding the variability in response to treatment uses a combination of multivariate statistics (i.e. chemometrics) and metabolic profiling to predict metabolism and toxicity of a drug. It is also called metabolomics or pharmaco-metabolomics as it could identify, qualitatively and quantitatively analyze a set of metabolites in biological matrices involved in biochemical pathways (metabolome), and monitor the interaction 
of genes and environment. The value of metabolomics is the possibility of discovering and determining biological markers as indicators, for example in the development of the disease, the effects and toxicity of the drug. In the last decade, intensive work has been done to discover metabolome which will be specific to hepatotoxicity or even DILI. Additionally, rapid detection of metabolites in biological fluids using nuclear magnetic resonance and mass spectrophotometry, as well as metabolomics will introduce the method in the early diagnosis and prognosis of DILI in the future. ${ }^{20}$

\section{Conclusion}

Despite the large number of drugs with proven hepatotoxic potential and the development of diagnostic methods and criteria for assessing causal relationship and monitoring, definitive diagnosis of drug-induced liver injury is still a challenge and is an excluding diagnosis. In order to prevent DILI, it is suggested that doctors and pharmacists are educated about the safe drug use and identification of clinical symptoms of liver damage, risk factors, monitoring of liver function in the treatment with hepatotoxic drugs, updating instructions for use of medicines in terms of drug hepatotoxicity, continuous monitoring and reporting of adverse drug reactions.

\section{Reference}

1. Björnsson E. Drug-induced liver injury in clinical practice. Aliment Pharmacol Ther 2010; 32: 3-13. http://dx.doi.org/10.1111/j.1365-2036.2010.04320.x

2. Kim SH, Naisbitt DJ. Update on Advances in Research of Idiosyncratic Drug Induced Liver Injury. Allergy Asthma Immunol Res 2016;8:3-11. http://dx.doi.org/10.4168/aair.2016.8.1.3

3. Björnsson E, Olsson R. Suspected drug induced liver fatalities reported to the WHO database. Dig Liv Dis 2006;38:33-8. http://dx.doi.org/10.1016/j.dld.2005.06.004

4. Chen M, Suzuki A, Borlak J, Andrade RJ, Lucena MI. Druginduced liver injury: Interactions between drug properties and host factors. J Hepatology 2015; 63:503-14. http://dx.doi.org/10.1016/j.jhep.2015.04.016

5. Lewis JH, Ahmed M, Shobassy A, Palese C. Drug-induced liver disease. Curr Opin Gastroenterol 2006; 22:223-33. http://dx.doi.org/10.1097/o1.mog.oooo218958.40441.fd

6. Abboud G., Kaplowitz N. Drug-Induced Liver Injury. Drug Saf 2007; 30: 277-94. http://dx.doi.org/10.2165/00002018-200730040-00001

7. Suzuki A, Andrade RJ, Bjornsson E, Lucena MI, William ML, Yuen NA et al. Drugs Associated with Hepatotoxicity and their Reporting Frequency of Liver Adverse Evenets in VigiBase Drug Sad 2010;33:503-22.

8. Stirnimann G, Kessebohm K, Lauterburg B. Liver injury caused by drugs. Swiss Med Wikly.2010; 140:w13080.

9. Verma S, Kaplowitz N. Diagnosis, management and prevention of drug-induced liver injury. Gut 2009; 58: 155564. http://dx.doi.org/10.1136/gut.2008.163675

10. Adams DH, Ju C, Ramaiah SK, Uetrecht J, Jaeschke H. Mechanisms of immune-mediated liver injury. Toxicol Sci 2010;115:307-21. http://dx.doi.org/10.1093/toxsci/kfqoo9

11. Lammert C, Bjornsson E, Niklasson A, Chalasani N. Oral medications with significant hepatic metabolism at higher risk for hepatic adverse events. Hepatology 2010;51:615-20. http://dx.doi.org/10.1002/hep.23317

12. Suzuki A, Andrade RJ, Björnsson E, Lucena MI, Lee WM, Yuen NA, et al. Drugs Associated with Hepatotoxicity and their Reporting Frequency of Liver Adverse Events in VigiBaseTM. Drug Saf 2010; 33: 503-22. http://dx.doi.org/10.2165/11535340-000000000-00000

13. Fontana RJ, Seeff LB, Andrade RJ, Björnsson E, Day CP, Serrano J, et al. Standardization of Nomenclature and Causality Assessment in Drug-Induced Liver Injury: Summary of a Clinical Research Workshop. Hepatology 2010; 52: 730-42. http://dx.doi.org/10.1002/hep.23696

14. Khoury T, Rmeileh AA, Yosha L, Benson AA, Daher S, Mizrahi M. Drug Induced Liver Injury: Review with a Focus on Genetic Factors, Tissue Diagnosis, and Treatment Options. J Clin Transl Hepatol 2015;28:99-108.

15. Andrade R, Robles M, Fernández-Castañer A, LópezOrtega S, López-Vega MC, Lucena MI. Assessment of druginduced of hepatotoxicity in clinical practice: A challenge for gastroenterologists. World J Gastroenterol 2007; 13: 32940.

http://dx.doi.org/10.3748/wjg.v13.i3.329

16. Bessone, F.; Hernandez, N.; Lucena, M.I.; Andrade, R.J.; on behalf of the Latin DILI Network (LATINDILIN) and Spanish DILI Registry. The Latin American DILI Registry Experience: A Successful Ongoing Collaborative Strategic Initiative. Int. J Mol. Sci 2016;17:313. h http://dx.doi.org/10.3390/ijms17030313

17. Ou P, Chen, Y, Li B, Zhang, Liu, X, Li F et al. Causes, clinical features and outcomes of drug-induced liver injury in hospitalized patients in a Chinese tertiary care hospital. Springer Plus 2015;4 :802. http://dx.doi.org/10.1186/s40064-015-1600-8

18. Björnsson ES. Hepatotoxicity by Drugs: The Most Common Implicated Agents. Int J Mol Sci.2015; 17, 224. http://dx.doi.org/10.339o/ijms17020224

19. Nezic L, Krähenbühl S, Rätz Bravo AE. Diclofenac induced liver injuries. Praxis (Bern 1994) 2012;101:371-9. http://dx.doi.org/10.1024/1661-8157/aooo880

20. Iruzubieta P, Arias-Loste MT, Barbier Torres L, Martinez Chantar ML, Crespo J. The Need for Biomarkers in Diagnosis and Prognosis of Drug-Induced Liver Disease: Does Metabolomics Have Any Role?.Biomed Res Int 2015;2015:386186. doi: 10.1155/2015/386186. http://dx.doi.org/10.1155/2015/386186 


\section{Lijekovima izazvana oštećenja jetre: patogeneza, kliničke karakteristike i monitoring}

\section{SAŽETAK}

Uvod: Lijekovima izazvana oštećenja jetre (drug induced liver injury-DILI) su po učestalosti rijetke, ali potencijalno životno ugrožavajuće neželjene reakcije na lijekove. DILI, patofiziološki i histopatološki, se teško razlikuju od akutnih ili hroničnih oboljenja jetre izazvanih drugim etiološkim uzročnicima. Oštećenje jetre može nastati direktno, dejstvom aktivne supstance ili indirektno, preko metabolita, a najčešće je dozno-zavisno i predvidljivo, ili nepredvidljivo, nastalo reakcijom idiosinkrazije, imunološke i neimunološke patogeneze i najvjerovatnije nezavisno od doze primjenjenog lijeka.

Metode: $U$ ovom specijalnom članku smo prikazali rezultate istraživanja o lijekovima koji najčešće izazivaju oštećenje jetre, dijagnostičke procjene, monitoring $\mathrm{i}$ ishode DILI, objavljene u publikacijama citiranim u naučnoj medicinskoj bazi MEDLINE/ PubMed, u periodu od 2006. do 2015. godine.

Rezultati: Incidenca DILI je u različitim regijama u svijetu i dalje nepoznata, ali se procjenjuje na 2-19 slučajeva/100.000 stanovnika/ godišnje u evropskim i američkim istraživanjima, odnosno preko 90 slučajeva/100.000 stanovnika/godišnje u azijskim zemljama. Antimikrobni lijekovi (amoksicilin/klavulonat, eritromicin, flukloksacilin, izoniazid), antiinflamatorni i analgo-antipiretici (diklofenak, paracetamol), hipolipemijski lijekovi (lipofilni statini) i različiti antiepileptici predstavljaju najčešće lijekove koji izazivaju oštećenje jetre.

Zaključak: Savremenim analitičkim postupcima do danas je otkriveno nekoliko pouzdanih biomarkera, iako nijedan nije dovoljno specifičan i senzitivan za DILI, tako da se dijagnostička i prognostička procjena DILI i dalje zasniva na kliničkoj i farmakološkoj anamnezi, važećim RUCAM kriterijima za DILI, te laboratorijskim nalazima jetrene funkcije.

Ključne riječi: lijekovi, hepatotoksičnost, idiosinkrazija, farmakogenetika, RUCAM kriterijumi 